\title{
Characterization of the Bacterial Community Associated with Methane and Odor in a Pilot-Scale Landfill Biocover under Moderately Thermophilic Conditions
}

\author{
Hyoju Yang ${ }^{1}$, Hyekyeng Jung ${ }^{1}$, Kyungcheol $\mathrm{Oh}^{2}$, Jun-Min Jeon ${ }^{2}$, and Kyung-Suk Cho ${ }^{1 *}$ \\ ${ }^{1}$ Department of Environmental Science and Engineering, Ewha Womans University, Seoul 03760, Republic of Korea \\ ${ }^{2}$ Green Environmental Complex Center, Suncheon 57992, Republic of Korea
}

A pilot-scale biocover was constructed at a sanitary landfill and the mitigation of methane and odor compounds was compared between the summer and non-summer seasons. The average inlet methane concentrations were $22.0 \%, 16.3 \%$, and $31.3 \%$, and the outlet concentrations were $0.1 \%$, $0.1 \%$, and $0.2 \%$ during winter, spring, and summer, respectively. The odor removal efficiency was $\mathbf{9 8 . 0} \%$ during summer, compared to $96.6 \%$ and $\mathbf{9 9 . 6} \%$ during winter and spring, respectively. No deterioration in methane and odor removal performance was observed even when the internal temperature of the biocover increased to more than $40^{\circ} \mathrm{C}$ at midday during summer. During summer, the packing material simultaneously degraded methane and dimethyl sulfide (DMS) under both moderately thermophilic $\left(40-50^{\circ} \mathrm{C}\right)$ and mesophilic conditions $\left(30^{\circ} \mathrm{C}\right)$. Hyphomicrobium and Brevibacillus, which can degrade methane and DMS at $40^{\circ} \mathrm{C}$ and $50^{\circ} \mathrm{C}$, were isolated. The diversity of the bacterial community in the biocover during summer did not decrease significantly compared to other seasons. The thermophilic environment of the biocover during summer promoted the growth of thermotolerant and thermophilic bacterial populations. In particular, the major methaneoxidizing species were Methylocaldum spp. during summer and Methylobacter spp. during the nonsummer seasons. The performance of the biocover remained stable under moderately thermophilic conditions due to the replacement of the main species and the maintenance of bacterial diversity. The information obtained in this study could be used to design biological processes for methane and odor removal during summer and/or in subtropical countries.

Keywords: Methane, odor, thermophile, thermotolerance, bacterial community, biological system

Received: March 3, 2021 Accepted: April 20, 2021

First published online: April 21, 2021

* Corresponding author Phone: +82-2-32772393 E-mail: kscho@ewha.ac.kr

Supplementary data for this paper are available on-line only at http://jmb.or.kr.

pISSN 1017-7825 eISSN 1738-8872

Copyright(C) 2021 by The Korean Society for Microbiology and Biotechnology

\section{Introduction}

Methane is a significant greenhouse gas that has a 28-36 times stronger effect on global warming than carbon dioxide [1]. Landfills are a major source of methane due to the anaerobic digestion of organic matter [2], during which odor compounds, including hydrogen sulfide $\left(\mathrm{H}_{2} \mathrm{~S}\right)$, methanethiol, dimethyl sulfide (DMS), and volatile organic compounds, are also produced as byproducts [3-5]. Odor compounds are not only a nuisance but also pose a potential hazard to human health at high concentrations, with long-term exposure often leading to emotional stress and physical symptoms such as anxiety, headaches, vomiting, eye irritation, and respiratory problems [6-9]. Therefore, the mitigation of both methane and odor is necessary for anaerobic digestion processes.

Methane and odor compounds emitted by anaerobic digestion can be mitigated using biological, chemical, or physical treatment [3,10-12]. Biological treatment is more environmentally friendly and safer than chemical and physical approaches because it does not require the use of chemicals and can be conducted at normal temperatures and pressures $[3,10,11]$. Biological treatment also offers high treatment efficiency, simple systems, and low treatment costs $[3,12]$. Therefore, biological systems such as biocovers and biowindows have attracted attention as promising technologies for the control of the methane and odor compounds emitted from landfills $[10,11]$.

Microbial activity, which determines the performance of biological treatment systems [13], is primarily influenced by environmental factors such as temperature, $\mathrm{pH}$, and moisture content $[3,14]$. For example, if the temperature of the biological treatment system is outside the range that most microorganisms can tolerate, the microbial activity is dramatically lower [14]. Most biological systems designed to mitigate the methane and odor compounds emitted by landfills employ mesophilic microorganisms [15-17]. Because the activity of mesophilic microbes decreases rapidly at low temperatures, it could be expected that the performance of biological treatment systems would deteriorate during winter. However, this is not the case because the internal temperature of these 
systems is maintained at around $8-18^{\circ} \mathrm{C}$ due to the heat generated by the biodegradation of methane and odor compounds and the effect of insulating materials $[10,11,18]$.

Mesophilic microorganisms are generally less active under moderately thermophilic conditions of $40^{\circ} \mathrm{C}$ or more. At midday during summer, the temperature inside biological treatment systems may rise to over $40^{\circ} \mathrm{C}$ due to the effects of solar radiation. Information on the composition and dynamics of the microbial community under moderately thermophilic conditions is thus essential when designing and setting the operating parameters for biological treatment systems during the hot season or in subtropical countries, but there is little information available on this. Therefore, in this study, the methane and odor removal performance of a pilot-scale biocover during the summer and non-summer seasons was compared. In particular, the structure of the bacterial community during summer was characterized and compared with the non-summer seasons. In addition, the degradation of methane and odor compounds by the packing material sampled from the biocover during summer was evaluated under moderately thermophilic conditions. Thermotolerant or thermophilic methane- and odordegrading bacteria were also isolated and their roles in the degradation of methane and odor compounds investigated.

\section{Materials and Methods \\ Packing Material for the Biocover}

A pilot-scale biocover was constructed at the Gwangyang Sanitary Landfill, located at latitude $34^{\circ} 58^{\prime} 0^{\prime \prime}$ and longitude $127^{\circ} 38^{\prime} 35^{\prime \prime}$. This sanitary landfill began operation in 1996 and has a total disposal capacity of $3,145,291 \mathrm{~m}^{3}[10,19]$. The packing material for the biocover was a mixture of soil, perlite (Kyungdong One Co. Ltd., Korea), food waste compost, and earthworm cast (Kumhosilup, Korea). The physiochemical characteristics of these materials were described previously by Lee et al. [10]. The soil, which had been used as an interim landfill cover, was provided by the landfill facility, and the food waste compost was acquired from the Gwangyang Food Waste Resource Facility (Korea). Perlite was used to increase the gas permeability of the biocover [10, 11]. The compost and earthworm cast were used as bacterial sources for the simultaneous removal of methane and odor compounds $[10,11]$. Based on preliminary testing, the ratio of perlite, soil, food waste compost, and earthworm cast was set at 2.5:2.5:0.6:0.6 (v/v). The initial moisture and organic content of the mixture were $16.44 \pm 0.13 \%$ and $5.67 \pm 0.02 \%$, respectively.

\section{Construction of the Pilot-Scale Biocover and Packing Material}

A schematic diagram of the biocover $(2.5 \mathrm{~m}$ wide $\times 2.5 \mathrm{~m}$ long $\times 1.2 \mathrm{~m}$ deep $)$ is presented in Fig. S1. For thermal insulation, polystyrene foam boards $(5 \mathrm{~cm}$ thick) were placed along the inside of the walls. The solid waste was first covered with a $0.23-\mathrm{m}$ thick layer of gravel (particle diameter of $2-5 \mathrm{~cm}$ ) and then a polypropylene non-woven textile sheet (Kyungdong One Co. Ltd.,). A 0.9-m-thick soil layer was placed on top of the textile cover. A perforated pipeline was installed at the bottom of the biocover and connected to polyvinyl chloride (PVC) pipes for biocover inlet gas sampling. An acrylic chamber $(2.5 \mathrm{~m}$ wide $\times 2.5 \mathrm{~m}$ long $\times 0.3 \mathrm{~m}$ high $)$ was installed on the surface of the biocover for gas sampling from the biocover surface (i.e., biocover outlet gas sampling). Biocover performance was monitored for 260 days from December 2016 to August 2017.

Ambient Temperature, Precipitation, and Physicochemical Properties of the Packing Material

Ambient temperature and precipitation measurements during the experimental period were obtained from the Gwangyang Automatic Weather Station operated by the Korea Meteorological Administration. The packing material in the biocover was sampled between 11 and 12 oclock on days $0,40,68,99,133,163,198,238$, and 252 at 0-15 cm (upper layer), $15-30 \mathrm{~cm}$ (middle layer), and 30-50 cm (bottom layer) from the surface of the biocover. Immediately before taking the sample, the temperature of the packing material in each layer was measured using a portable digital thermometer (SDT200, Summit Co. Ltd., Korea).

After being passed through a $2-\mathrm{mm}$ sieve, the samples were stored at $4^{\circ} \mathrm{C}$ for the assessment of their physicochemical properties $\left(\mathrm{pH}\right.$, moisture content, and organic matter content) and at $-20^{\circ} \mathrm{C}$ for the analysis of the bacterial community. The moisture and organic matter content of the samples were measured based on the Korean Standard Soil Analysis Method [10] and the Korean Standard Waste Analysis Method [10], respectively. To measure the $\mathrm{pH}$ of the samples, $3 \mathrm{~g}$ of each sample was mixed with $20 \mathrm{~mL}$ of distilled water, and the supernatant was collected after allowing the particles to settle for $5 \mathrm{~min}$. The $\mathrm{pH}$ of the resulting supernatant was measured with a pH meter (Thermo Orion 535A, USA).

\section{Gas Analysis}

Gas samples from the inlet port and the surface of the biocover were collected on days 12, 39, 63, 98, 124, 165, 182,223 , and 253. The gas sampling was conducted using the same method described in a previous study [10]. The methane concentration in the gas samples was measured using a gas chromatograph equipped with a flame ionization detector [10]. The methane levels were also measured in the field using a biogas check analyzer (Geotechnical Instruments, UK) [10]. The concentrations of 22 odor compounds designated as key offensive odors by the Korean Odor Prevention Law were analyzed using the same methods described in a previous study [10]. Complex odor compounds were analyzed using the odor dilution ratio (ODR) [20]. Details on the calculation of the ODR are available in Lee et al. [10]. The removal efficiency of the methane and complex odor compounds was calculated as the difference in the concentration of the target compounds between the inlet and the surface of the biocover. 
Bacterial Community Analysis Using Illumina MiSeq Sequencing

The packing material sampled at $15-30 \mathrm{~cm}$ on days $0-252$ was used to characterize the bacterial community dynamics in the biocover. For DNA extraction, $0.5 \mathrm{~g}$ of each sample was transferred to a microtube from the stored bottle, and the DNA was extracted using a NucleoSpin Soil Kit (Macherey-Nagel GmbH, Germany) and a MiniBeadBeater-8 system (BioSpec, USA). DNA extraction was performed following the manufacturer's instructions. The extracted DNA samples were eluted with $50 \mu \mathrm{l}$ of an elution buffer and stored at $-20^{\circ} \mathrm{C}$ before analysis. The extracted DNA was used as a PCR template to analyze the bacterial community with an Illumina MiSeq sequencing platform (Macrogen Inc., Korea) using the same method described in our previous paper [11]. Each composite primer was designed based on $515 \mathrm{f}$ and $806 \mathrm{r}$ primers [21]. Sequences shorter or longer than the target sequence were cut using CD-HIT-OTU [22], and chimera and noise were eliminated. The sequences with over 97\% similarity were classified into operational taxonomic units (OTUs). Using the UCLUST algorithm [23], the taxonomy for each OTU was assigned based on the 16S rRNA RDP database. The Chaol richness estimator and the Shannon index were also calculated [24]. The obtained sequence data were deposited into the National Center for Biotechnology Information (NCBI) Sequence Read Archive (https://www.ncbi.nlm.nih.gov/) under accession number SRP185598. Bacterial community dynamics were analyzed using principal component analysis (PCA) with UniFrac [25] and CANOCO 4.5 software (Microcomputer Power, USA).

\section{Simultaneous Removal of Methane and Dimethyl Sulfide by the Packing Materials under Moderately Thermophilic Conditions}

The simultaneous removal of methane and odor compounds was evaluated at $40^{\circ} \mathrm{C}$ and $50^{\circ} \mathrm{C}$ for three packing material samples taken on day 252 at $0-15 \mathrm{~cm}, 15-30 \mathrm{~cm}$, and $30-50 \mathrm{~cm}$ from the surface of the biocover. In order to compare the removal efficiency under moderately thermophilic and medium temperature conditions, the same experiment was carried out at $30^{\circ} \mathrm{Cs}$. DMS was selected as a representative odor compound. Five grams of the wet samples and $20 \mathrm{ml}$ of nitrated mineral salt (NMS) medium were added to 600-ml serum bottles. The NMS medium contained $1.0 \mathrm{~g} / \mathrm{l} \mathrm{MgSO} \cdot 7 \mathrm{H}_{2} \mathrm{O}, 0.2 \mathrm{~g} / \mathrm{l} \mathrm{CaCl}_{2} \cdot 6 \mathrm{H}_{2} \mathrm{O}, 1.0 \mathrm{~g} / 1 \mathrm{KNO}_{3}, 0.272 \mathrm{~g} / \mathrm{K} \mathrm{KH}_{2} \mathrm{PO}_{4}$, and $0.717 \mathrm{~g} / \mathrm{l}$ $\mathrm{Na}_{2} \mathrm{HPO}_{4} \cdot 12 \mathrm{H}_{2} \mathrm{O}$. The serum bottles were sealed with a butyl rubber stopper, and then methane gas from a cylinder (99\%; Dong-A Gases, Korea) was injected into the bottles to a final concentration of 50,000 ppm [13]. In addition, DMS solution (99\%; Acros Organics, Belgium) was injected into the bottles to a final concentration of $5,000 \mathrm{ppm}$. The serum bottles were incubated at $30^{\circ} \mathrm{C}, 40^{\circ} \mathrm{C}$, and $50^{\circ} \mathrm{C}$ and $180 \mathrm{rpm}$ in a shaking incubator. In order to prevent the stopper from falling out due to the expansion of the gas inside the serum bottle at $40^{\circ} \mathrm{C}$ and $50^{\circ} \mathrm{C}, 60 \mathrm{ml}$ of the gas inside the serum bottle was removed using a syringe before putting the serum bottle into the incubator. The gas in the headspace of each serum bottle was periodically sampled using gas-tight syringes to measure the concentration of methane and DMS with a gas chromatography system (GC 7890, Agilent Technologies, USA) equipped with a $30 \mathrm{~m} \times 320 \mu \mathrm{m} \times 1.8 \mu \mathrm{m}$ capillary column (J\&W Scientific, Inc., ISA) and a flame ionization detector (Agilent Technologies). The operating temperature of the oven, injector, and detector was $100^{\circ} \mathrm{C}, 230^{\circ} \mathrm{C}$, and $230^{\circ} \mathrm{C}$, respectively. The degradation rates for the methane and DMS were calculated as the reduction in the methane and DMS from their initial concentration to a concentration below 2,000 ppm and $500 \mathrm{ppm}$, respectively, divided by the incubation time per unit dry weight of the sample.

\section{Isolation and Identification of Methane- and DMS-Degrading Bacteria under Moderately Thermophilic Conditions}

To isolate methane- and DMS-degrading bacteria at $40^{\circ} \mathrm{C}$ and $50^{\circ} \mathrm{C}$, enrichment cultures were developed. Packing material samples taken at $0-15 \mathrm{~cm}, 15-30 \mathrm{~cm}$, and $30-50 \mathrm{~cm}$ from the surface of the biocover on day 252 were mixed in equal amounts with each other. Five grams of the mixed sample was placed in each of two 600-ml serum bottles containing $20 \mathrm{ml}$ of NMS medium. After sealing the bottles with butyl rubber stoppers, methane gas and DMS solution were injected to final concentrations of 50,000 ppm and 5,000 ppm, respectively. One bottle was incubated at $40^{\circ} \mathrm{C}$, and the other was incubated at $50^{\circ} \mathrm{C}$ in a shaking incubator $(180 \mathrm{rpm})$. When the concentrations of methane and DMS in the headspace of each bottle decreased below the detection limit, methane gas and DMS solution were re-injected and the bottle was re-incubated at $40^{\circ} \mathrm{C}$ or $50^{\circ} \mathrm{C}$. After repeating this process five times, $10 \mathrm{ml}$ of the $1^{\text {st }}$ enriched culture was transferred into $10 \mathrm{ml}$ of fresh NMS medium in a $600 \mathrm{ml}$ serum bottle, and methane and DMS were injected into the bottle. Each bottle was incubated at $40^{\circ} \mathrm{C}$ or $50^{\circ} \mathrm{C}$, and methane and DMS were re-supplied when their concentration fell below the detection limit before re-incubation. After repeating this process four times, $10 \mathrm{ml}$ of the $2^{\text {nd }}$ enriched culture was transferred into $10 \mathrm{ml}$ of fresh NMS medium, methane and DMS were supplied, and the bottle was incubated at $40^{\circ} \mathrm{C}$ or $50^{\circ} \mathrm{C}$.

After repeating this replenishment four times, the $3^{\text {rd }}$ enriched culture was diluted with NMS medium, and the diluted culture was spread on NMS-agar $(20 \mathrm{~g} / \mathrm{l})$ plates. The inoculated plates were incubated at $40^{\circ} \mathrm{C}$ or $50^{\circ} \mathrm{C}$ in a 5-L reactor, which was connected to a 3-L Tedlar bag containing 50,000 ppm of methane and 5,000 ppm of DMS. After incubation for 1-2 months, distinguishable colonies on the plates were carefully transferred to fresh NMSagar plates and incubated in the same manner as described above. This process was repeated several times to produce four pure strains $(\mathrm{HJ} 1, \mathrm{HJ} 2, \mathrm{HJ} 3$, and $\mathrm{HJ} 4)$ from the $40^{\circ} \mathrm{C}$-enriched cultures and two pure strains (HJ5 and HJ6) from the $50^{\circ} \mathrm{C}$-enriched cultures.

The simultaneous degradation of methane and DMS by the isolates in the serum bottles was evaluated at $40^{\circ} \mathrm{C}$ or $50^{\circ} \mathrm{C}$ using the same method as described in Section 2.6. To identify the isolates, genomic DNA samples were extracted using NucleoSpin Soil Kits (Macherey-Nagel GmbH Düren, Germany), and amplified with PCR using the primer set 340F (5'-TCCTACGGGAGGCAGCAG-3') and 805R (5'-GACTACHVGGGTATCTAATCC-3') [26]. The sequence data were deposited in the NCBI Sequence Read Archive (https://www.ncbi.nlm.nih.gov/) 
under the accession number MK577721 for the strain HY1, MK577720 for HY2, MK577719 for HY3, MK577718 for HY4, MK639430 for HY5, and MK577717 for HY6.

\section{Results and Discussion}

\section{Variation in the Environmental Parameters}

Environmental factors such as temperature, precipitation, moisture content, organic matter content, and $\mathrm{pH}$ affect biocover performance $[10,11,27-32]$. Fig. 1 presents the ambient temperature, precipitation, internal temperature, and physical characteristics of the packing material at different depths in the biocover. The average ambient temperature during winter (from December to February), spring (from March to May), and summer (from June to August) was $-2.9-13.1^{\circ} \mathrm{C}, 1.1-26.3^{\circ} \mathrm{C}$, and $18.0-31.5^{\circ} \mathrm{C}$, respectively (Fig 1A). Monthly precipitation was the highest in August (Fig. 1B). During winter and spring, the internal temperature tended to increase with greater distance from the surface of the biocover, with a range of $20-30^{\circ} \mathrm{C}$ at midday (Fig. $1 \mathrm{C}$ ), while that during summer was $41-49^{\circ} \mathrm{C}$, even though the maximum ambient temperature was $21.4-37.0^{\circ} \mathrm{C}$ (Figs. $1 \mathrm{~A}$ and 1C). There were four main reasons for this higher internal temperature: (1) the heat generated by biodegradation in the waste layer at the bottom of the biocover, (2) heat from the biodegradation of methane and odor compounds in the biocover, (3) heat from intense sunlight during the middle of the day, and (4) thermal insulation due to the polystyrene foam boards within the biocover (Fig. S1). Jung et al. [11] also reported that the temperature inside a biowindow was higher than the ambient temperature during winter and spring. The optimal temperature range for the growth and activity of methane- and odor-degrading bacteria has been shown to be 25$35^{\circ} \mathrm{C}[10,11,33,34]$ because most of these species are mesophiles. Thus, the temperature inside the biocover during winter and spring was maintained within a suitable range for the simultaneous biodegradation of methane and odor compounds, but the internal temperature during the summer period was not favorable for mesophilic bacteria (Fig. 1C).

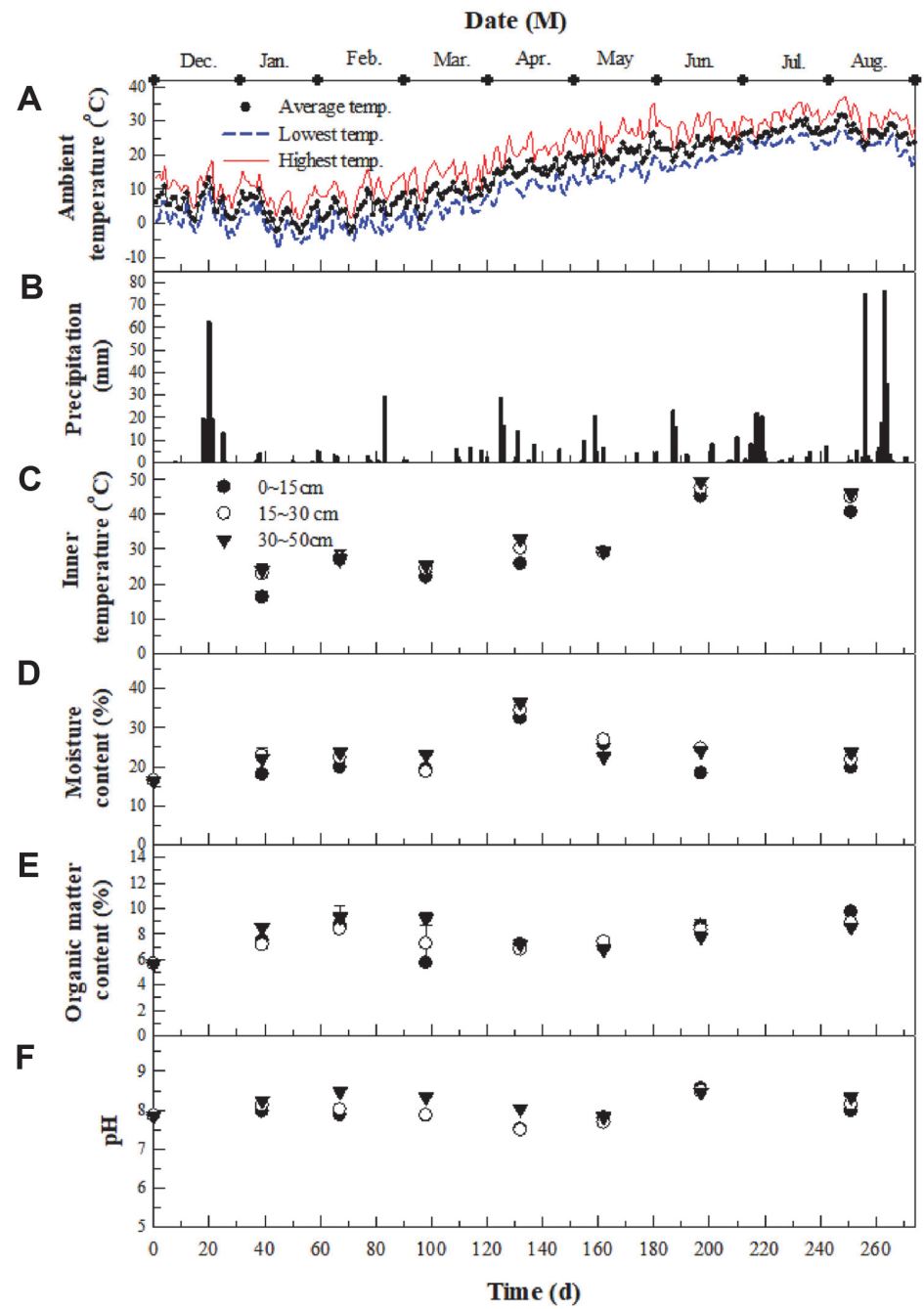

Fig. 1. Time profiles of the ambient temperature (A), precipitation (B), internal temperature (C), moisture content (D), organic matter content $(\mathrm{E})$, and $\mathrm{pH}(\mathrm{F})$ of the packing material in the biocover. 
The moisture content, organic matter content, and $\mathrm{pH}$ of the packing material in the biocover are presented in Figs. 1D-1F. The moisture content in the biocover mostly remained at around $20-25 \%$ at all sample depths, though it did increase to $30 \%$ on day 124 due to heavy precipitation (Fig. 1D). Cho and Ryu [3] reported that the optimal moisture content for biocover performance was $25-50 \%$. The moisture content of the biocover in the present study thus fell within a suitable range for the simultaneous degradation of methane and odor compounds. During summer, despite the high evaporation rate, the moisture content in the biocover was maintained at a suitable level due to the frequent precipitation (Figs. 1A, 1B, and 1D). The successful removal of methane and odor compounds within a biocover with a low organic matter content of $5-10 \%$ has been reported $[10,11,18]$. In addition, most methane- and/or odor-degrading bacteria exhibit optimal activity at a neutral $\mathrm{pH}[3,34,35]$. Considering these previous results, the moisture content and $\mathrm{pH}$ of the biocover were favorable for methane- and odor-degrading bacteria.

\section{Methane and Odor Removal during Summer}

Fig. $2 \mathrm{~A}$ presents a time profile of the methane concentration and removal efficiency. The methane concentration at the biocover inlet was below $32 \%$ during winter and spring but ranged from $20-38 \%$ during summer. It is believed that the inlet methane concentration was higher during summer because the biodegradation of landfill waste was higher under thermophilic conditions. During the 254-day experimental period, the methane removal efficiency was over $98 \%$ despite the fluctuation in the inlet concentration (Fig. 2A). The average inlet methane concentration during winter, spring, and summer was $22.0 \%, 16.3 \%$, and $31.3 \%$, respectively, and the outlet concentration was $0.1 \%, 0.1 \%$, and $0.2 \%$, respectively (Fig. $2 \mathrm{~B}$ ). The methane removal by the biocover was compared with that of the soil cover at a site adjacent to the biocover [19]. The methane concentration at the surface of the biocover (i.e., the outlet) remained below $0.4 \%$, while that at the surface of the landfill soil cover fluctuated between $0.05 \%$ and $27.8 \%$ (Fig. 2B).

A

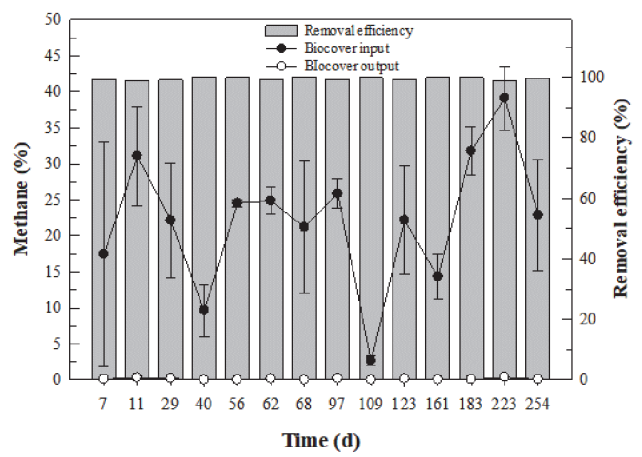

B

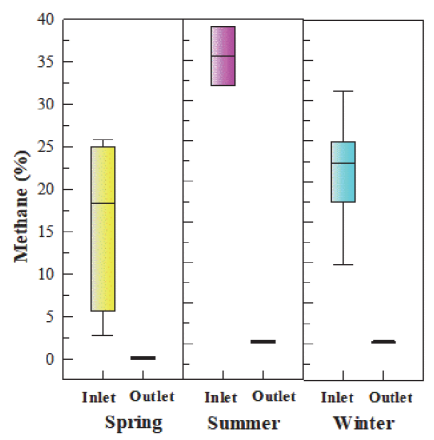

C

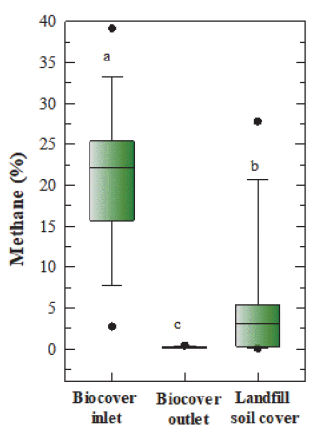

Fig. 2. Removal of methane within the biocover. (A) Time profile for the methane concentration and removal efficiency. (B) Seasonal changes in the methane concentration at the biocover inlet and outlet. (C) Comparison of the methane concentration at the biocover inlet, the biocover outlet, and the landfill soil cover. The landfill soil cover was monitored for 240 days (Dec. 2016 to Aug. 2017) at the soil surface at the same landfill (Yun et al., 2017). In the box plot, the boxes represent the 25th, 50th (median), and 75th percentiles, and the error bars indicate the 10th and 90th percentiles. Different letters indicate a significant difference within each plot $(p<0.05)$.

A

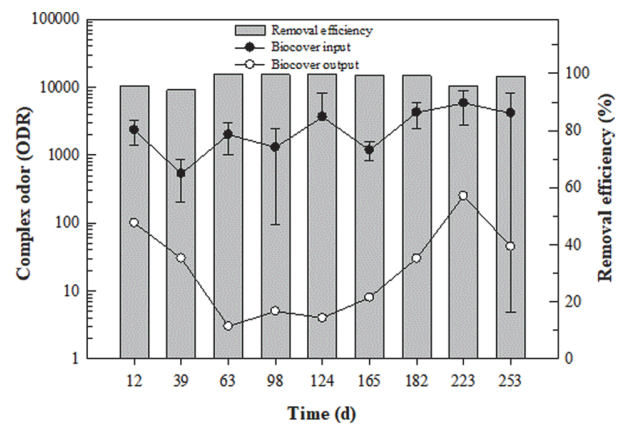

B

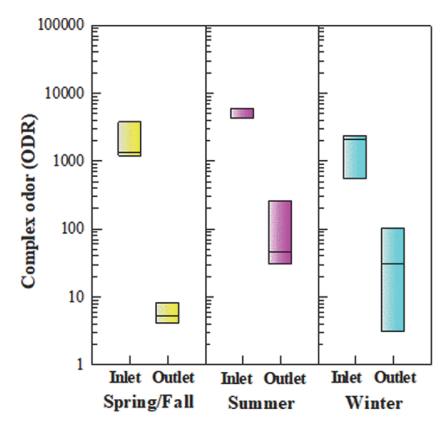

C

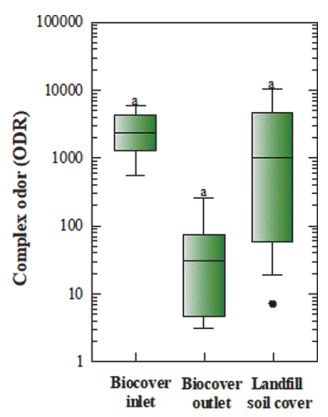

Fig. 3. Removal of odor within the biocover. (A) Time profile for complex odor compounds (ODR) and the removal efficiency. (B) Seasonal changes in the ODR at the biocover inlet and outlet. (C) Comparison of the ODR at the biocover inlet, the biocover outlet, and the landfill soil cover. The landfill soil cover was monitored for 240 days (Dec. 2016 to Aug. 2017) at the soil surface at the same landfill (Yun et al., 2017). In the box plot, the boxes represent the 25th, 50th (median), and 75th percentiles, and the error bars indicate the 10th and 90th percentiles. Different letters indicate a significant difference within each plot $(p<0.05)$. 
The concentration and removal efficiency for 22 odor compounds in the biocover are summarized in Table S1. Previous studies have reported that the key compounds that contribute to the complex odor intensity at the Gwangyang landfill are sulfur-containing compounds [10,11, 18, 19, 36]. Similar to previous studies, sulfurcontaining compounds were the primary contributors to the complex odor intensity in the present study (Table S1). The odor removal performance of the biocover is presented in Fig. 3. The average inlet ODR during summer (4735) was slightly higher than that during winter (1622) and spring (2046) (Figs. 3A and 3B). During summer, the average outlet ODR ranged from 30 to 100 , with an average removal efficiency of $98 \%$. The average odor removal efficiency was $96.6 \%$ during winter and $99.6 \%$ during spring. The ODR was 3-250 at the surface of the biocover across the entire sampling period but ranged from 7 to 10,000 at the surface of the landfill soil with no biocover (Fig. 3C).

In the pilot-scale biocover containing a mixture of soil, perlite, earthworm cast, and compost at a ratio of 6:2:1:1 $(\mathrm{v} / \mathrm{v})$, the methane and odor removal efficiency from the landfill gas was $85-96 \%$ and $93-98 \%$ during the spring and summer seasons, respectively [10]. A previous study reported that, across all seasons, odor removal by biocovers installed at a sanitary landfill ranged from 81 to $98 \%$ [18], which is similar to the biocover performance in the present study. In addition, there was no observed deterioration in methane or odor removal performance when the internal temperature of the biocover increased to more than $40^{\circ} \mathrm{C}$ at midday during the summer season.

\section{Bacterial Community Structure during Summer}

Table 1 summarizes the bacterial community in the biocover. The number of OTUs increased from 545 to 1060 between day 0 and day 113 and then settled down to 441-686. The Shannon index, which is used to evaluate the diversity of a bacterial community, fluctuated between 4.703 and 5.587. The Shannon index during summer was 4.703-5.470, while that during winter and spring was 4.839-5.587, showing that the diversity of the bacterial community did not decrease significantly during summer. Principal component analysis (PCA) was also conducted to compare the structure of the bacterial community by season (Fig. 4), leading to the creation of three clear groups. The composition of the community during summer (days 198-252) differed from that during the winter and spring seasons (days 40-163).

Table 1. Bacterial community analysis results for the biocover.

\begin{tabular}{ccccc}
\hline Sampling time $(\mathrm{d})$ & No. of OTUs $^{\mathrm{a}}$ & Chaol $^{\mathrm{b}}$ & Shannon $^{\mathrm{c}}$ & Good coverage $^{\mathrm{d}}$ \\
\hline 0 & 545 & 648 & 5.445 & 0.998 \\
40 & 708 & 873 & 5.227 & 0.996 \\
68 & 874 & 983 & 4.839 & 0.999 \\
99 & 996 & 1160 & 5.411 & 0.997 \\
133 & 1060 & 1193 & 5.587 & 0.998 \\
163 & 650 & 801 & 4.890 & 0.989 \\
$\mathbf{1 9 8}$ & $\mathbf{4 4 1}$ & $\mathbf{6 0 3}$ & $\mathbf{5 . 3 7 3}$ & $\mathbf{0 . 9 8 5}$ \\
$\mathbf{2 3 8}$ & $\mathbf{6 8 6}$ & $\mathbf{8 1 8}$ & $\mathbf{4 . 7 0 3}$ & $\mathbf{0 . 9 9 8}$ \\
$\mathbf{2 5 2}$ & $\mathbf{6 7 3}$ & $\mathbf{8 8 5}$ & $\mathbf{5 . 4 7 0}$ & $\mathbf{0 . 9 8 9}$ \\
\hline
\end{tabular}

${ }^{a}$ Operational taxonomic units

${ }^{\mathrm{b}} \mathrm{Chao} 1$ is used to evaluate bacterial community richness.

'The Shannon index is used to evaluate the diversity within a bacterial community.

${ }^{\mathrm{d}}$ Good coverage is calculated as $\mathrm{C}=1-(\mathrm{s} / \mathrm{n})$, where $s$ is the number of unique OTUs and $n$ is the number of individuals in the sample. This index provides a relative measure of how well the sample represents the wider community.

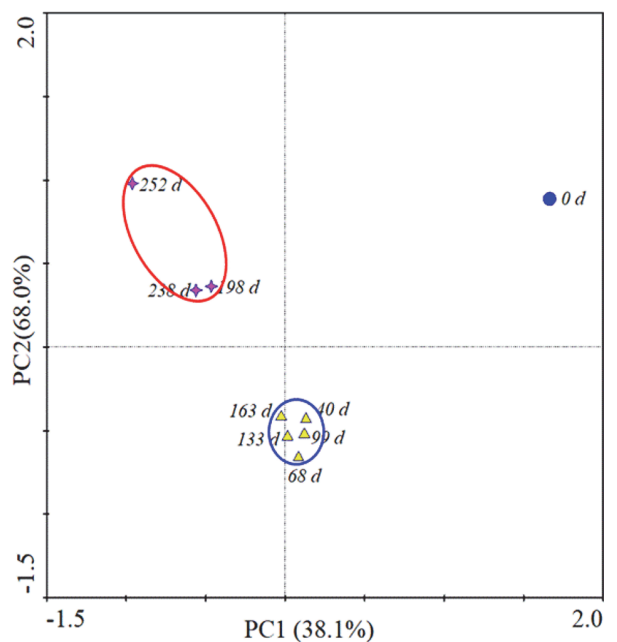

Fig. 4. Principal component analysis (PCA) of the structure of the bacterial community in the biocover. The community structure was analyzed in duplicate. 
Table 2 presents the relative abundance of the bacterial genera in the biocover at each sampling point. The correlation between the bacterial community and environmental parameters is shown in Table S2. The generation of a thermophilic environment in the biocover during summer promoted the growth of thermophilic heterotrophs, including Bellilinea, Rhodothermus, Thermanaerothrix, and Thermomarinilinea (Tables 2 and S2) [37-40]. Many Rhodothermus spp. experience large fluctuations in environmental conditions, and these can utilize a wide variety of carbon sources using thermostable enzymes (Bjornsdottir et al., 2006), suggesting that the genus may contribute to odor degradation during summer. In contrast, because Bellilinea, Thermanaerothrix, and Thermomarinilinea are obligate anaerobes that can also produce methane via anaerobic metabolism, it is believed that they contribute little to methane or odor degradation $[37,39,40]$. In addition, even though the genus Ornatilinea is known as strictly anaerobic, mesophilic, and organotrophic, its dominance increased during summer because some of its species exhibit optimal growth at $42-45^{\circ} \mathrm{C}$ [41].

The relative abundance of the genus Hyphomicrobium increased from $0.35-1.10 \%$ during winter and spring to 0.94-6.42\% during summer (Tables 2 and S2). Hyphomicrobium, a methylotrophic genus, can degrade sulfurcontaining odor compounds such as DMS and hydrogen sulfide as well as methane and methanol [42-44]. This genus has previously been identified as a dominant genus in landfill biocovers for methane and odor mitigation $[11,18]$. Hyphomicrobium has also been reported to be the dominant genus in thermophilic processes, including sludge composting and thermophilic biotrickling filtering, and is a mesophilic aerobe $[45,46]$. Thus, this genus is

Table 2. Comparison of the relative abundance of bacterial genera in the biocover.

\begin{tabular}{|c|c|c|c|c|c|c|c|c|c|c|}
\hline & \multirow{2}{*}{ Genus } & \multicolumn{9}{|c|}{ Sampling time (d) } \\
\hline & & 0 & 40 & 68 & 99 & 133 & 163 & 198 & 238 & 252 \\
\hline Non- & Acinetobacter & 15.70 & $-*$ & - & - & - & 1.10 & - & - & - \\
\hline \multirow[t]{32}{*}{ Methanotroph } & Actinomadura & - & 0.90 & - & - & - & - & - & 1.13 & - \\
\hline & Actinophytocola & - & - & - & - & - & - & - & 1.16 & - \\
\hline & Advenella & 1.20 & 3.00 & 1.90 & 0.90 & - & - & - & - & - \\
\hline & Arthrobacter & 8.00 & - & - & 1.20 & - & - & - & - & - \\
\hline & Bacillus & 1.00 & - & - & - & - & 2.20 & 1.10 & 8.53 & 1.00 \\
\hline & Bellilinea & - & - & - & - & - & - & 4.00 & - & 1.90 \\
\hline & Brevibacterium & - & - & - & - & - & - & - & 1.88 & - \\
\hline & Cellulosimicrobium & - & - & - & 1.50 & - & - & - & - & - \\
\hline & Chryseolinea & - & - & - & - & - & 1.10 & - & - & - \\
\hline & Desertibacter & - & - & - & - & - & - & - & - & 1.70 \\
\hline & Dokdonella & - & - & - & - & 1.60 & - & - & - & - \\
\hline & Homoserinibacter & 1.10 & - & 1.20 & 1.30 & 1.20 & - & - & - & - \\
\hline & Hydrogenophaga & - & - & 1.30 & - & - & - & - & - & - \\
\hline & Hyphomicrobium & 0.44 & 0.46 & 0.35 & 0.49 & 0.52 & 1.10 & 1.20 & 6.42 & 0.94 \\
\hline & Ignavibacterium & - & - & - & - & - & - & - & - & 1.80 \\
\hline & Lascolabacillus & - & - & 1.20 & - & - & - & - & - & - \\
\hline & Luteimonas & - & 7.50 & 1.60 & 1.70 & 1.20 & 2.00 & - & 4.80 & - \\
\hline & Microbispora & 1.50 & - & - & - & - & - & - & - & - \\
\hline & Nonomuraea & - & 4.90 & 2.00 & 1.80 & 1.20 & 0.90 & - & - & - \\
\hline & Ohtaekwangia & - & 1.70 & 0.90 & 1.70 & 1.70 & 4.10 & 1.50 & 7.28 & 5.90 \\
\hline & Ornatilinea & - & - & - & - & - & - & 2.20 & - & 2.70 \\
\hline & Pedobacter & 8.10 & - & - & - & - & - & - & - & - \\
\hline & Planococcus & 8.30 & - & - & 1.20 & - & - & - & - & - \\
\hline & Porticoccus & 2.90 & - & - & - & - & - & - & - & - \\
\hline & Pseudomonas & 3.80 & 1.10 & - & - & - & - & - & - & - \\
\hline & Pseudoxanthomonas & - & 1.00 & - & - & - & - & - & - & - \\
\hline & Rhodothermus & - & - & - & - & - & - & 4.60 & - & 6.10 \\
\hline & Rummeliibacillus & 1.20 & - & - & - & - & 1.70 & - & - & - \\
\hline & Serpens & 15.70 & 27.20 & 13.90 & 13.40 & 12.40 & 7.30 & 18.10 & - & 2.00 \\
\hline & Streptomyces & 0.70 & 1.70 & 0.90 & 1.40 & 0.52 & 0.64 & 0.28 & 0.91 & 0.57 \\
\hline & Thermanaerothrix & 0.80 & 1.40 & - & 1.00 & 1.50 & - & 4.80 & 0.83 & 12.30 \\
\hline & Thermomarinilinea & - & - & - & - & - & - & 13.90 & 3.55 & 17.90 \\
\hline \multirow[t]{7}{*}{ Methanotroph } & Methylocaldum & 1.30 & 2.40 & 0.90 & 1.60 & 2.40 & 5.80 & 9.00 & 24.86 & 23.40 \\
\hline & Methylococcus & - & - & - & 0.40 & 0.80 & 0.80 & 0.20 & 3.46 & - \\
\hline & Methylobacter & 0.80 & 15.90 & 41.90 & 37.80 & 37.30 & 37.70 & 13.00 & 6.60 & 6.60 \\
\hline & Methylomicrobium & - & 0.10 & - & 0.40 & 0.10 & 0.10 & - & - & - \\
\hline & Methylosarcina & - & - & 0.10 & 0.20 & 0.50 & 0.60 & - & - & - \\
\hline & Methylomonas & - & - & - & - & 0.20 & - & - & - & - \\
\hline & Methylocystis & - & - & - & 0.10 & 0.20 & 0.10 & 0.10 & - & - \\
\hline Others & & 27.46 & 30.73 & 31.85 & 31.91 & 36.66 & 32.76 & 26.02 & 28.59 & 15.19 \\
\hline Total & & 100 & 100 & 100 & 100 & 100 & 100 & 100 & 100 & 100 \\
\hline
\end{tabular}

*-, Less than $0.1 \%$ 
likely to have played a major role in the degradation of methane and odor in the biocover even during summer due to its thermotolerant characteristics.

The pattern for the genus Ohtaekwangia during the experimental period was similar to that of Hyphomicrobium. The dominance of Ohtaekwangia increased with higher ambient temperatures, with a range of $0.90-1.70 \%$ during winter, $1.70-4.10 \%$ during spring, and 1.50-7.28\% during summer (Tables 2 and S2). Similar to our results, this genus has been detected during the thermophilic, maturation, and mesophilic stages during olive mill waste composting, even though Ohtaekwangia is an aerobic mesophile [47]. Ohtaekwangia has been reported to co-exist with methanotrophs such as Methylocystis and Methylosinus in a biofilter for methane mitigation [48]. In addition, Ohtaekwangia was one of the dominant bacterial genera in a biocomplex textile installed at a sanitary landfill [36]. Based on these results, Ohtaekwangia may be directly or indirectly associated with methane and odor biodegradation across all seasons.

The relative abundance of Bacillus fluctuated widely, with a range of 1.00-8.53\% across all seasons (Tables 2 and S2). Mesophilic and thermophilic Bacillus species have been reported [49, 50], while thermotolerant methylotrophic Bacillus strains that can utilize the RuMP pathway for formaldehyde fixation have been isolated [51, 52]. This genus has been identified as one of the most dominant in biocovers for odor control [18]. These results suggest that the genus Bacillus is an important player in methane and odor mitigation during both the summer and nonsummer seasons.

The most dominant methanotrophs were Methylocaldum during summer and Methylobacter during winter and spring (Table 2). The relative abundance of Methylobacter increased to $37.30-41.90 \%$ in winter and spring but fell to $6.60 \%$ during summer, while that of Methylocaldum tended to increase with higher ambient temperatures, reaching $24.86 \%$ and $23.40 \%$ on days 238 and 252, respectively (Tables 2 and S2). Thermophilic Methylocaldum has previously been isolated from a high-temperature hot spring and is known to have a broad range of growth temperatures between $30^{\circ} \mathrm{C}$ to $61^{\circ} \mathrm{C}$, with optimal growth at $55^{\circ} \mathrm{C}$ [53]. In addition, thermotolerant and thermophilic Methylocaldum species, with an optimal growth temperature above $40^{\circ} \mathrm{C}$, have been isolated from agricultural soil and the effluent of a hot spring [54]. Methylobacter and Methylocaldum were also the dominant methanotrophs in a pilot-scale biocover, biowindow, and biocomplex textile installed at a landfill [10, 11, 36]. These results suggest that Methylocaldum, which adapts well to high temperatures, plays a key role in methane oxidation during the summer season, while Methylobacter is important during winter and spring (Tables 2 and S2).

Simultaneous Removal of Methane and DMS by the Packing Material under Moderately Thermophilic Conditions

Fig. 5 presents time profiles for methane and DMS degradation by the packing material sampled during summer at $30^{\circ} \mathrm{C}, 40^{\circ} \mathrm{C}$, and $50^{\circ} \mathrm{C}$. All of the packing material samples from the top $(0-15 \mathrm{~cm})$, middle $(15-30 \mathrm{~cm})$,
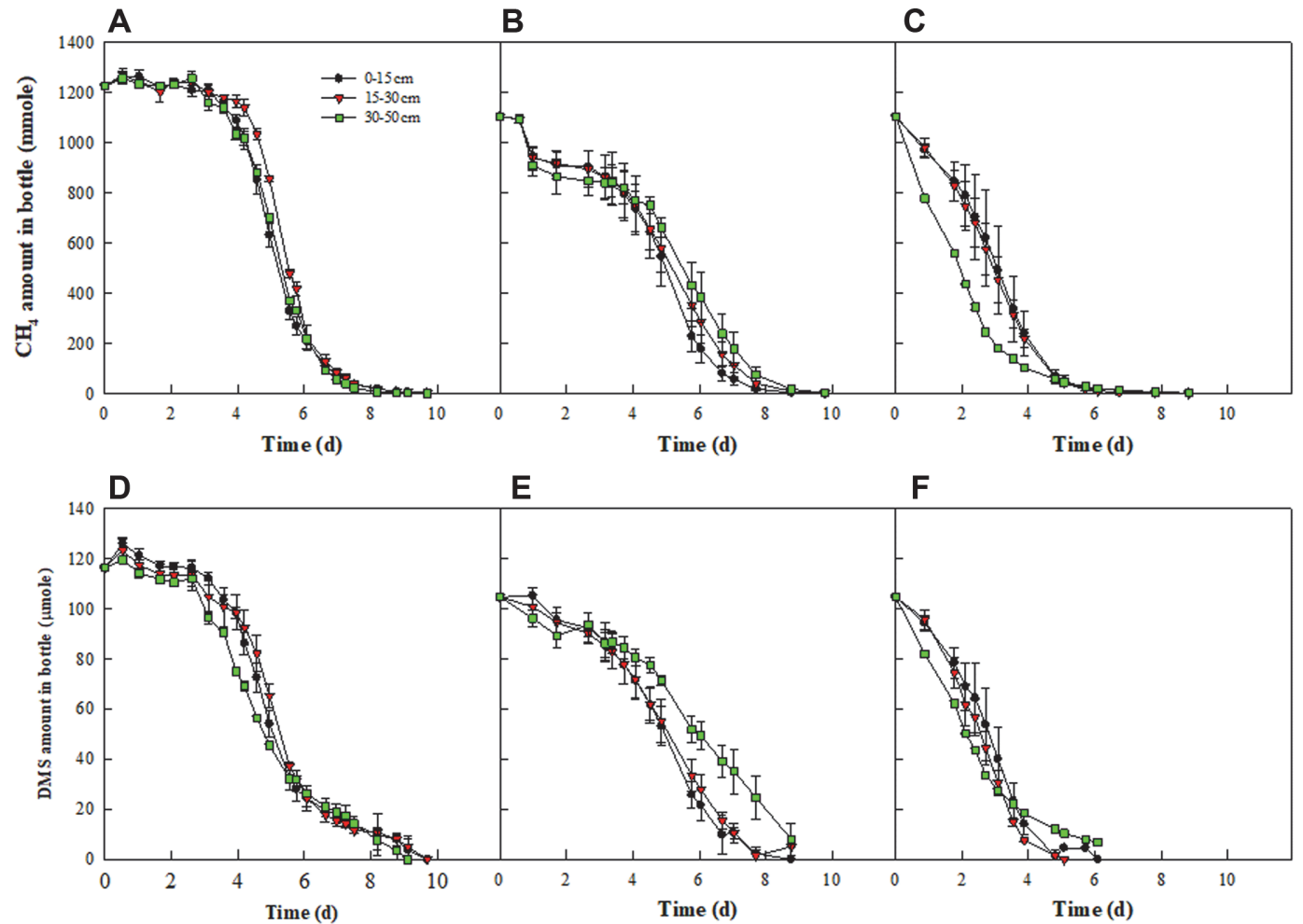

Fig. 5. Time profiles for methane (A-C) and DMS (D-F) degradation by the packing material sampled at 0 $15,15-30$, and $30-50 \mathrm{~cm}$ from the surface of the biocover. Incubation temperatures: (A) and (D) $30^{\circ} \mathrm{C},(\mathrm{B})$ and (D) $40^{\circ} \mathrm{C}$, and $(\mathbf{C})$ and $(\mathbf{F}) 50^{\circ} \mathrm{C}$. 
Table 3. Comparison of the methane and DMS degradation rate by the packing material at 30,40 , and $50^{\circ} \mathrm{C}$.

\begin{tabular}{|c|c|c|c|}
\hline \multirow{2}{*}{ Temp. $\left({ }^{\circ} \mathrm{C}\right)$} & \multirow{2}{*}{ Sampling layer $(\mathrm{cm})$} & \multicolumn{2}{|c|}{ Degradation rate for the packing material ( $\mu$ mol.g-dry sample $\left.{ }^{-1} \cdot h^{-1}\right)$} \\
\hline & & $\mathrm{CH}_{4}$ & DMS \\
\hline \multirow[t]{3}{*}{$30^{\circ} \mathrm{C}$} & $0-15$ & $1.502 \pm 0.060^{\mathrm{C}, \mathrm{D} *}$ & $0.136 \pm 0.001^{\mathrm{D}, \mathrm{E}}$ \\
\hline & $15-30$ & $1.614 \pm 0.060^{\mathrm{C}}$ & $0.148 \pm 0.004^{\mathrm{D}}$ \\
\hline & $30-50$ & $1.682 \pm 0.074^{\mathrm{C}}$ & $0.154 \pm 0.005^{\mathrm{D}}$ \\
\hline \multirow[t]{3}{*}{$40^{\circ} \mathrm{C}$} & $0-15$ & $1.388 \pm 0.060^{\mathrm{C}, \mathrm{D}}$ & $0.124 \pm 0.004^{\mathrm{E}, \mathrm{F}}$ \\
\hline & $15-30$ & $1.335 \pm 0.060^{\mathrm{D}}$ & $0.125 \pm 0.004^{\mathrm{E}, \mathrm{F}}$ \\
\hline & $30-50$ & $1.407 \pm 0.060^{\mathrm{C}, \mathrm{D}}$ & $0.110 \pm 0.004^{\mathrm{F}}$ \\
\hline \multirow[t]{3}{*}{$50^{\circ} \mathrm{C}$} & $0-15$ & $2.052 \pm 0.060^{\mathrm{B}}$ & $0.208 \pm 0.004^{\mathrm{C}}$ \\
\hline & $15-30$ & $2.101 \pm 0.060^{\mathrm{B}}$ & $0.228 \pm 0.004^{\mathrm{B}}$ \\
\hline & $30-50$ & $3.059 \pm 0.074^{\mathrm{A}}$ & $0.256 \pm 0.005^{\mathrm{A}}$ \\
\hline
\end{tabular}

${ }^{\star}$ Different letters denote a significant difference $(n=3, p<0.05)$.

and bottom $(30-50 \mathrm{~cm})$ layers of the biocover simultaneously degraded methane and DMS under moderately thermophilic conditions $\left(40-50^{\circ} \mathrm{C}\right)$ and mesophilic conditions $\left(30^{\circ} \mathrm{C}\right)$. Table 3 presents the degradation rates for methane and DMS at different temperatures. The degradation rate for both methane and $\mathrm{DMS}$ at $50^{\circ} \mathrm{C}$ was significantly higher than at $30^{\circ} \mathrm{C}$ and $40^{\circ} \mathrm{C}$ and increased with a greater sampling depth, with the degradation rate for methane and DMS highest at $30-50 \mathrm{~cm}\left(3.059 \pm 0.074\right.$ and $0.256 \pm 0.005 \mu \mathrm{mol} \cdot \mathrm{g}$-dry sample $\mathrm{e}^{-1} \cdot \mathrm{h}^{-1}$, respectively). Because the internal temperature during summer increased to $41-49^{\circ} \mathrm{C}$ at midday during summer (Fig. 1C), the methane and DMS degradation was higher under moderately thermophilic conditions than under mesophilic conditions. Degradation was also assumed to be highest at $30-50 \mathrm{~cm}$ because the internal temperatures tended to rise as the depth of the biocover increased (Fig. 1C).

Isolation and Identification of Thermophilic Methanotrophs and Simultaneous Removal of Methane and DMS

Four methane- and DMS-degrading bacterial species - Inquilinus sp. HJ1, Amycolatopsis sp. HJ2, Streptomyces sp. $\mathrm{HJ} 3$, and Chitinophaga sp. $\mathrm{HJ} 4$ - were isolated at $40^{\circ} \mathrm{C}$ (Figs. $6 \mathrm{~A}$ and $6 \mathrm{~B}$ ), though they were not able to degrade methane or DMS at $50^{\circ} \mathrm{C}$ (data not shown). Brevibacillus sp. HJ5 and Hyphomicrobium sp. HJ6, which were isolated from the enrichment culture at $50^{\circ} \mathrm{C}$, simultaneously degraded methane and DMS at $50^{\circ} \mathrm{C}$ and at $40^{\circ} \mathrm{C}$ (Figs. 6C and 6D). Methane and DMS degradation by the isolates at $50^{\circ} \mathrm{C}$ was faster than at $40^{\circ} \mathrm{C}$. This is consistent

A

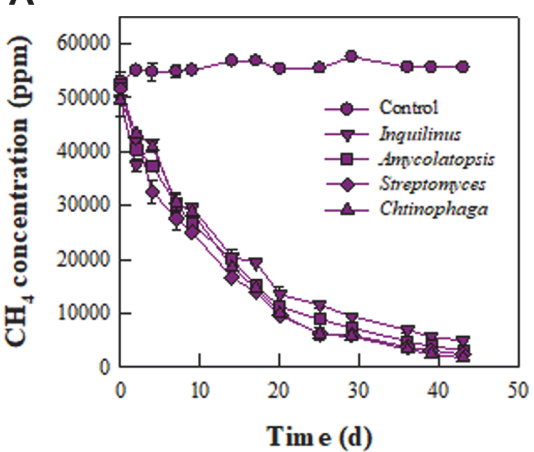

C

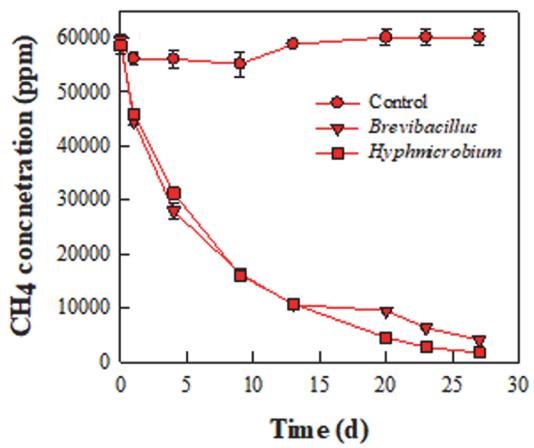

B

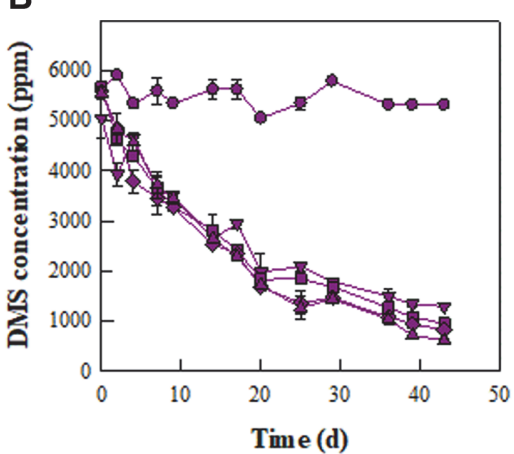

D

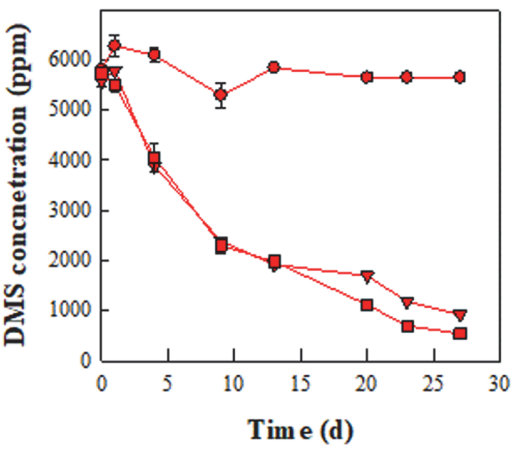

Fig. 6. Time profiles for methane (A and C) and DMS (B and D) degradation by the isolates from the biocover. Incubation temperatures: (A) and $(\mathbf{B}) 40^{\circ} \mathrm{C}$ and $(\mathbf{C})$ and $(\mathbf{D})$ at $50^{\circ} \mathrm{C}$. 
with the experimental results, which found that degradation by the packing material was greater at $50^{\circ} \mathrm{C}$ than at $40^{\circ} \mathrm{C}$ (Table 3).

The bacterial community results reveal that the abundance of Hyphomicrobium during summer was higher during the non-summer seasons (Table 2). This genus can utilize $\mathrm{C} 1$ compounds such as methane and methanol and deodorize $\mathrm{H}_{2} \mathrm{~S}$, methanethiol, and DMS [42-44] and has previously been reported to be dominant in biological treatment systems for the removal of methane and DMS $[11,36]$. The abundance of Brevibacillus in the biocover ranged from $0.01 \%$ to $0.04 \%$ (data not shown). Some Brevibacillus species are thermophilic and others are mesophilic [55, 56], while Chebbi et al. [56] reported that Brevibacillus sp. CAT37 degraded malodorous thiols. The abundance of Streptomyces, a representative Actinobacteria genus, in the biocover was $0.52-1.40 \%$ during the non-summer seasons and $0.57-0.91 \%$ during summer (Table 2). A methane-utilizing Streptomyces species has been isolated from paddy soil [57], and Streptomyces griseus has been used in a biofilter for odor removal [58]. Some Streptomyces strains also exhibit thermotolerance [59].

Although three strains belonging to Inquilinus, Chitinophaga, and Amycolatopsis were isolated from the enrichment cultures in this study (Fig. 6), their abundance in the bacterial community was below $0.01 \%$ (data not shown). The Inquilinus sp. isolated from a ginseng soil field is a strictly aerobic, mesophilic heterotroph [60], while another Inquilinus strain has been identified as a plant-growth-promoting endophytic bacterium [61]. To the best of our knowledge, no previous studies have reported its thermotolerance or its methane or odor degradation ability. A Chitinophaga strain isolated from soil was shown to be an aerobic heterotroph that could grow at 15$42^{\circ} \mathrm{C}$ [62]. Chitinophaga has also been detected as one of the dominant genera in a sludge-composting process [45]. Amycolatopsis methanolica is a facultatively methylotrophic actinomycete [63], while Amycolatopsis rugosa can grow at $10-45^{\circ} \mathrm{C}$ and decarboxylate odorous acids such as acetate and propionate [64].

Except for Inquilinus, a review of past research confirmed that the genera of the isolated strains exhibit heat resistance and/or thermophilic properties. Previous studies indicate that Hyphomicrobium, Streptomyces, and Amycolatopsis have methylotrophic characteristics, meaning that they utilize methane as a carbon source [42-44, 57, 63]. Previous research has also found that Hyphomicrobium and Brevibacillus have strong potential for DMS degradation $[42-44,56]$. In the present study, only preliminary results for methane and DMS degradation at $40^{\circ} \mathrm{C}$ and $50^{\circ} \mathrm{C}$ by the isolated strains were presented. Further investigation is required to determine the mechanisms underlying methane and DMS degradation by the isolates under moderately thermophilic conditions.

It took around 8 to 10 days for the packing material to completely degrade the methane and DMS at different depths in the biocover (Fig. 5). However, it took more than 40 days for methane and DMS to be completely decomposed by pure bacteria isolated from the enrichment culture at $40^{\circ} \mathrm{C}$ (Figs. $6 \mathrm{~A}$ and $6 \mathrm{~B}$ ). In addition, the degradation rates for Brevibacillus sp. HJ5 and Hyphomicrobium sp. HJ6, which are capable of decomposing methane and DMS at $50^{\circ} \mathrm{C}$, were also slower than for the packing material (Fig. 6). This suggests that a variety of bacteria are involved in the degradation of methane and DMS in the packing material, leading to a higher degradation rate. In general, the higher the diversity of a microbial community, the more diverse its functions and the higher its functional stability against disturbance $[65,66]$. In this study, the bacterial diversity in the biocover was maintained within a certain range (Table 1 ). The bacterial community results show that the dominant bacterial species involved in the degradation of methane and odor changed as the environmental conditions changed. For example, as the ambient temperature increased, the major methane-oxidizing bacteria were Methylocaldum spp., replacing Methylobacter spp. Due to the change in the dominant species and the maintenance of bacterial diversity, the methane and odor removal performance of the biocover was not significantly disrupted by changes in the environmental conditions, such as the ambient temperature and precipitation.

In this study, the simultaneous removal of methane and odor in the biocover was compared between the summer and non-summer seasons. The biocover performance for the methane and odor compounds did not deteriorate even when the internal temperature of the biocover increased to more than $40^{\circ} \mathrm{C}$ at midday during summer. The packing material sampled from the biocover in summer was able to degrade methane and DMS at $40-50^{\circ} \mathrm{C}$, while the isolated bacteria simultaneously degraded methane and $\mathrm{DMS}$ at $40^{\circ} \mathrm{C}$ and $/$ or $50^{\circ} \mathrm{C}$. The diversity of the bacterial community in the biocover also remained constant regardless of the season, though the relative abundance of thermotolerant and thermophilic bacteria increased during summer. The major methaneoxidizing bacterial group shifted from Methylobacter during the non-summer seasons to Methylocaldum during summer. These results indicate that the methane and odor removal ability of a biocover can be maintained under moderately thermophilic conditions due to the replacement of the main species and the maintenance of bacterial diversity. Taken as a whole, the information regarding the bacterial community dynamics under moderately thermophilic conditions revealed in the present study could be used to design biological treatment systems for methane and odor mitigation during summer and/or in subtropical countries.

\section{Acknowledgments}

This research was supported by the Korean Ministry of Environment as a Converging Technology Project (201500164003).

\section{Conflict of Interest}

The authors have no financial conflicts of interest to declare. 


\section{References}

1. Intergovernmental Panel on Climate Change. 2014. Synthesis report. Contribution of working groups I, II and III to the fifth assessment report of the intergovernmental panel on climate change. Geneva, Switzerland. Available at: https://www.ipcc.ch/pdf/ assessment-report/ar5/syr/SYR_AR5_FINAL_full_wcover.pdf Accessed 27 February, 2021).

2. Allen G. 2016. Rebalancing the global methane budget. Nature 538: 46-48.

3. Cho KS, Ryu HW. 2009. Biotechnology for the mitigation of methane emission from landfills. Microbiol. Biotechnol. Lett. 37: 293-305.

4. Duan Z, Lu W, Li D, Wang H. 2014. Temporal variation of trace compound emission on the working surface of a landfill in Beijing, China. Atmos.Environ. 88: 230-238.

5. Fang JJ, Yang N, Cen DY, Shao LM, He PJ. 2012. Odor compounds from different sources of landfill: characterization and source identification. Waste Manage 32: 1401-1410.

6. Capelli L, Sironi S, Del Rosso R, Centola P, Rossi A, Austeri C. 2011. Olfactometric approach for the evaluation of citizens' exposure to industrial emissions in the city of Terni, Italy. Sci. Total. Environ. 409: 595-603.

7. Hayes JE, Stevenson RJ, Stuetz RM. 2014. The impact of malodour on communities: a review of assessment techniques. Sci. Total Environ. 500-501: 395-407.

8. Palmiotto M, Fattore E, Paiano V, Celeste G, Colombo A, Davoli E. 2014. Influence of a municipal solid waste landfill in the surrounding environment: toxicological risk and odor nuisance effects. Environ. Int. 68: 16-24.

9. Wu C, Liu J, Yan L, Chen H, Shao H, Meng T. 2015. Assessment of odor activity value coefficient and odor contribution based on binary interaction effects in waste disposal plant. Atmos. Environ. 103: 231-237.

10. Lee YY, Jung H, Ryu HW, Oh KC, Jeon JM, Cho KS. 2018. Seasonal characteristics of odor and methane mitigation and the bacterial community dynamics in an on-site biocover at a sanitary landfill. Waste Manag. 71:277-286.

11. Jung H, Oh KC, Ryu HW, Jeon JM, Cho KS. 2019. Simultaneous mitigation of methane and odors in a biowindow using a pipe network. Waste Manag. 100: 45-56.

12. Pecorini I, Rossi E, Iannelli R. 2020. Mitigation of methane, NMVOCs and odor emissions in active and passive biofiltration systems at municipal solid waste landfills. Sustainability 12: 3203.

13. Lee YY, Hong S, Cho KS. 2019. Design and shelf stability assessment of bacterial agents for simultaneous removal of methane and odors. J. Environ. Sci. Health Part A-Tox. Hazard. Subst. Environ. Eng. 54: 906-913.

14. Einola JK, Karhu AE, Rintala JA. 2008. Mechanically-biologically treated municipal solid waste as a support medium for microbial methane oxidation to mitigate landfill greenhouse emissions. Waste Manag. 28: 97-111.

15. Qi G, Pan Z, Yamamoto Y, Andriamanohiarisoamanana FJ, Yamashiro T, Iwasaki M, et al. 2019. The survival of pathogenic bacteria and plant growth promoting bacteria during mesophilic anaerobic digestion in full-scale biogas plants. Anim. Sci. J. 90: 297-303.

16. Singh G, Jain VK, Singh A. 2017. Effect of temperature and other factors on anaerobic digestion process, responsible for bio gas production. J. Theor. Appl. Mech. 12: 637-657.

17. Walker TWN, Kaiser C, Strasser F, Herbold CW, Leblans NIW, Woebken D, et al. 2018. Microbial temperature sensitivity and biomass change explain soil carbon loss with warming. Nat. Clim. Chang. 8: 885-889.

18. Yun J, Jung H, Ryu HW, Oh KC, Jeon JM, Cho KS. 2018a. Odor mitigation and bacterial community dynamics in on-site biocovers at a sanitary landfill in South Korea. Environ. Res. 166: 516-528.

19. Yun J, Oh KC, Jeon JM, Ryu HW, Cho KS. 2017. Seasonal emission characteristics of odors and methane from soil cover layers in a sanitary landfill. J. Odor Indoor Environ. 16: 315-328.

20. Dravnieks A, Jarke F. 1980. Odor threshold measurement by dynamic olfactometry: Significant operational variables. J. Air Pollut. Contr. Assoc. 30: 1284-1289.

21. Pearce MM, Hilt EE, Rosenfeld AB, Zilliox MJ, Thomas-White K, Fok C, et al. 2014. The female urinary microbiome: a comparison of women with and without urgency urinary incontinence. mBio 5: e01283-01214.

22. Li W, Fu L, Niu B, Wu S, Wooley J. 2012. Ultrafast clustering algorithms for metagenomic sequence analysis. Brief. Bioinform. 13: 656-668.

23. Edgar RC. 2010. Search and clustering orders of magnitude faster than BLAST. Bioinformatics 26: 2460-2461.

24. Park JE, Lee BT, Kim BY, Son A. 2018. Bacterial community analysis of stabilized soils in proximity to an exhausted mine. Environ. Eng. Res. 23: 420-429.

25. Lozupone C, Hamady M, Knight R. 2006. UniFrac-an online tool for comparing microbial community diversity in a phylogenetic context. BMC Bioinformatics 7: 371 .

26. Herlemann DP, Labrenz M, Jurgens K, Bertilsson S, Waniek JJ, Andersson AF. 2011. Transitions in bacterial communities along the $2000 \mathrm{~km}$ salinity gradient of the Baltic Sea. ISME J. 5: 1571-1579.

27. Zhang Y, Zhang H, Jia B, Wang W, Zhu W, Huang T, et al. 2012. Landfill CH4 oxidation by mineralized refuse: effects of $\mathrm{NH}_{4}{ }^{+}-\mathrm{N}$ incubation, water content and temperature. Sci. Total. Environ. 426: 406-413.

28. Bajar S, Singh A, Kaushik CP, Kaushik A. 2016. Evaluation and statistical optimization of methane oxidation using rice husk amended dumpsite soil as biocover. Waste Manag. 53: 136-143.

29. Karthikeyan OP, Chidambarampadmavathy K, Nadarajan S, Heimann K. 2016. Influence of nutrients on oxidation of low level methane by mixed methanotrophic consortia. Environ. Sci. Pollut. Res. 23: 4346-4357.

30. Ahoughalandari B, Cabral AR. 2017a. Influence of capillary barrier effect on biogas distribution at the base of passive methane oxidation biosystems: Parametric study. Waste Manag. 63: 172-187.

31. Ahoughalandari B, Cabral AR. 2017b. Landfill gas distribution at the base of passive methane oxidation biosystems: Transient state analysis of several configurations. Waste Manag. 69: 298-314.

32. Ahoughalandari B, Cabral AR. Leroueil S. 2018. Elements of design of passive methane oxidation biosystems: Fundamental and practical considerations about compaction and hydraulic characteristics on biogas migration. Geotech. Geol. Eng. 36: 2593-2609.

33. Cho KS, Jung H. 2017. Methane mitigation technology using methanotrophs: A review. Microbiol. Biotechnol. Lett. 45: 185-199.

34. Scheutz C, Kjeldsen P, Bogner JE, De Visscher A, Gebert J, Hilger HA, et al. 2009. Microbial methane oxidation processes and technologies for mitigation of landfill gas emissions. Waste Manag. Res. 27: 409-455.

35. Nanda S, Sarangi PK, Abraham J, 2012. Microbial biofiltration technology for odour abatement: An introductory review. J. Soil Sci. Environ. Manag. 3: 28-35.

36. Yun J, Jung H, Choi H, Oh KC, Jeon JM, Ryu HW, et al. 2018b. Performance evaluation of an on-site biocomplex textile as an alternative daily cover in a sanitary landfill, South Korea. Waste Manag. Res. 36: 1137-1145.

37. Yamada T, Imachi H, Ohashi A, Harada H, Hanada S, Kamagata Y, et al. 2007. Bellilinea caldifistulae gen. nov., sp. nov. and Longilinea arvoryzae gen. nov., sp. nov., strictly anaerobic, filamentous bacteria of the phylum Chloroflexi isolated from methanogenic propionate-degrading consortia. Int. J. Syst. Evol. Microbiol. 57: 2299-2306.

38. Bjornsdottir SH, Blondal T, Hreggvidsson GO, Eggertsson G, Petursdottir S, Hjorleifsdottir S, et al. 2006. Rhodothermus marinus: physiology and molecular biology. Extremophiles 10: 1-16.

39. Grégoire P, Fardeau ML, Joseph M, Guasco S, Hamaide F, Biasutti S, et al. 2011. Isolation and characterization of Thermanaerothrix daxensis gen. nov., sp. nov., a thermophilic anaerobic bacterium pertaining to the phylum "Chloroflexi", isolated from a deep hot aquifer in the Aquitaine Basin. Syst. Appl. Microbiol. 34: 494-497. 
40. Nunoura T, Hirai M, Miyazaki M, Kazama H, Makita H, Hirayama H, et al. 2013. Isolation and characterization of a thermophilic, obligately anaerobic and heterotrophic marine Chloroflexi bacterium from a Chloroflexi-dominated microbial community associated with a Japanese shallow hydrothermal system, and proposal for Thermomarinilinea lacunofontalis gen. nov., sp. nov. Microbes Environ. 28: 228-235.

41. Podosokorskaya OA, Bonch-Osmolovskaya EA, Novikov AA, Kolganova TV, Kublanov IV. 2013. Ornatilinea apprima gen. nov., sp. nov., a cellulolytic representative of the class Anaerolineae. Int. J. Syst. Evol. Microbiol. 63: 86-92.

42. De Bo I, Heyman J, Vincke J, Verstraete W, Van Langen-hove H. 2003. Dimethyl sulfide removal from synthetic waste gas using a flat poly(dimethylsiloxane)-coated composite mem-brane bioreactor. Environ. Sci. Technol. 37: 4228-4234.

43. Borodina E, Kelly DP, Rainey FA, Ward-Rainey NL, Wood AP. 2000. Dimethylsulfone as a growth substrate for novel methylotrophic species of Hyphomicrobium and Arthrobacter. Arch. Microbiol. 173: 425-437.

44. Hayes AC, Liss SN, Allen DG. 2010. Growth kinetics of Hyphomicrobium and Thiobacillus spp. in mixed cultures degrading dimethyl sulfide and methanol. Appl. Environ. Microbiol. 76: 5423-5431.

45. Fang Y, Jia X, Chen L, Lin C, Zhang H, Chen J. 2019. Effect of thermotolerant bacterial inoculation on the microbial community during sludge composting. Can. J. Microbiol. 65: 750-761.

46. Wei Z, Huang Q, Ye Q, Chen Z, Li B, Wang J. 2015. Thermophilic biotrickling filtration of gas-phase trimethylamine. Atmos. Pollut. Res. 6: $428-433$

47. Tortosa G, Castellano-Hinojosa A, Correa-Galeote D, Bedmar EJ. 2017. Evolution of bacterial diversity during two-phase olive mill waste ("alperujo") composting by $16 \mathrm{~S}$ rRNA gene pyrosequencing. Bioresour. Technol. 224: 101-111.

48. Limbri H, Gunawan C, Thomas T, Smith A, Scott J, Rosche B. 2014. Coal-packed methane biofilter for mitigation of green house gas emissions from coal mine ventilation air. PLoS One 9: e94641.

49. Wijnands LM, Dufrenne JB, Zwietering MH, van Leusden FM. 2006. Spores from mesophilic Bacillus cereus strains germinate better and grow faster in simulated gastro-intestinal conditions than spores from psychrotrophic strains. Int. J. Food Microbiol. 112: 120 -128.

50. Panda MK, Sahu MK, Tayung K. 2013. Isolation and characterization of a thermophilic Bacillus sp. with protease activity isolated from hot spring of Tarabalo, Odisha, India. Indian J. Microbiol. 5: 159-165.

51. Brooke AG, Watling EM, Attwood MM, Tempest DW. 1989. Environmental control of metabolic fluxes in thermotolerant methylotrophic Bacillus strains. Arch. Microbiol. 151: 268-273.

52. Al-Awadhi N, Mason CA. 1990. The process utility of thermotolerant methylotrophic bacteria: I. an evaluation in chemostat culture. Biotechnol. Bioeng. 36: 816-820.

53. Eshinimaev BT, Medvedkova KA, Khmelenina VN, Suzina NE, Osipov GA, Lysenko AM, et al. 2004. New thermophilic methanotrophs of the genus Methylocaldum. Microbiology 73: 448-456.

54. Bodrossy L, Holmes EM, Holmes AJ, Kovács KL, Murrell JC. 1997. Analysis of 16S rRNA and methane monooxygenase gene sequences reveals a novel group of thermotolerant and thermophilic methanotrophs, Methylocaldum gen. nov. Arch. Microbiol. 168: $493-503$.

55. Hadad D, Geresh S, Sivan A. 2005. Biodegradation of polyethylene by the thermophilic bacterium Brevibacillus borstelensis. J. Appl. Microbiol. 98: 1093-1100.

56. Chebbi A, Mhiri N, Rezgui F, Ammar N, Maalej A, Sayadi S, et al. 2015. Biodegradation of malodorous thiols by a Brevibacillus sp. strain isolated from a Tunisian phosphate factory. FEMS Microbiol. Lett. 362: fnv097.

57. Chen ZY, Wu WX, Min H, Chen MC, Zhao YH. 2000. Isolation and identification of two methane-utilizing strains of Streptomyces hygroscopicus. J. Zhejiang Univ. (Agriculture and Life Sciences) 26: 384-388.

58. Mohamed EF, Awad G, Andriantsiferana C, El-Diwany AI. 2016. Biofiltration technology for the removal of toluene from polluted air using Streptomyces griseus. Environ. Technol. 37: 1197-1207.

59. Szabó I, Benedek Á, Szabó IM, Barabás G. 2000. Feather degradation with a thermotolerant Streptomyces graminofaciens strain. World J. Microbiol. Biotechnol. 16: 253-255.

60. Jung HM, Lee JS, Bae HM, Yi TH, Kim SY, Lee ST, et al. 2011. Inquilinus ginsengisoli sp. nov., isolated from soil of a ginseng field. Int. J. Syst. Evol. Microbiol. 61: 201-204.

61. Afzal I, Iqrar I, Shinwari ZK, Yasmin A. 2016. Plant growth-promoting potential of endophytic bacteria isolated from roots of wild Dodonaea viscosa L. Plant Growth Regul. 81: 399-408

62. Kim MK, Jung HY. 2007. Chitinophaga terrae sp. nov., isolated from soil. Int. J. Syst. Evol. Microbiol. 57: 1721-1724.

63. de Boer L, Dijkhuizen L, Grobben G, Goodfellow M, Stackebrandt E, Parlett JH, Whitehead D, Witt D. 1990. Amycolatopsis methanolica sp. nov., a facultatively methylotrophic actinomycete. Int. J. Syst. Bacteriol. 40: 194-204.

64. Lechevalier MP, Prauser H, Labeda DP, Ruan JS. 1986. Two new genera of nocardioform actinomycetes: Amycolata gen. nov. and Amycolatopsis gen. nov. Int. J. Syst. Bacteriol. 36: 29-37.

65. Allison SD, Martiny JBH. 2008. Resistance, resilience, and redundancy in microbial communities. Proc. Natl. Acad. Sci. USA 105: 11512-11519.

66. Girvan MS, Campbell CD, Killham K, Prosser JI, Glover LA, 2005. Bacterial diversity promotes community stability and functional resilience after perturbation. Environ. Microbiol. 7: 301-313. 